\title{
The pharmacology of TD-8954, a potent and selective 5-HT4 receptor agonist with gastrointestinal prokinetic properties
}

\section{David T. Beattie ${ }^{1}{ }^{*}$, Scott R. Armstrong ${ }^{1}$, Ross G. Vickery ${ }^{2}$, Pamela R. Tsuruda ${ }^{3}$, Christina B. Campbell ${ }^{1}$, Carrie Richardson ${ }^{4}$, Julia L. McCullough ${ }^{4}$, Oranee Daniels ${ }^{2}$, Kathryn Kersey ${ }^{2}$, Yu-Ping Li ${ }^{5}$ and Karl H. S. Kim ${ }^{2}$}

\author{
Department of Pharmacology, Theravance, Inc., South San Francisco, CA, USA \\ ${ }^{2}$ Department of Clinical Pharmacology and Experimental Medicine, Theravance, Inc., South San Francisco, CA, USA \\ ${ }^{3}$ Department of Molecular and Cellular Biology, Theravance, Inc., South San Francisco, CA, USA \\ ${ }^{4}$ Formerly of Theravance, Inc., South San Francisco, CA, USA \\ ${ }^{5}$ Department of Biometrics, Theravance, Inc., South San Francisco, CA, USA
}

\section{Edited by:}

Angelo A. Izzo, University of Naples Federico II, Italy

\section{Reviewed by:}

Elisabetta Barocelli, University of Parma, Italy

Diego Curro, Catholic University of the Sacred Heart, Italy

\section{*Correspondence:}

David T. Beattie, Department of Pharmacology, Theravance, Inc., 901 Gateway Boulevard, South San Francisco, CA 94080, USA.

e-mail:dbeattie@theravance.com
This study evaluated the in vitro and in vivo pharmacological properties of TD-8954, a potent and selective $5-\mathrm{HT}_{4}$ receptor agonist. TD-8954 had high affinity $\left(\mathrm{pK}_{\mathrm{i}}=9.4\right)$ for human recombinant $5-\mathrm{HT}_{4(\mathrm{c})}\left(\mathrm{h}^{-}-\mathrm{HT}_{4(\mathrm{c})}\right)$ receptors, and selectivity $(>2,000$-fold) over all other 5 hydroxytryptamine (5-HT) receptors and non-5-HT receptors, ion channels, enzymes and transporters tested $(n=78)$. TD-8954 produced an elevation of cAMP in HEK-293 cells expressing the $\mathrm{h} 5-\mathrm{HT}_{4(\mathrm{c})}$ receptor $\left(\mathrm{pE} \mathrm{C}_{50}=9.3\right)$, and contracted the guinea pig colonic longitudinal muscle/myenteric plexus preparation $\left(\mathrm{pEC}_{50}=8.6\right)$. TD-8954 had moderate intrinsic activity in the in vitro assays. In conscious guinea pigs, subcutaneous administration of TD-8954 $(0.03-3 \mathrm{mg} / \mathrm{kg})$ increased the colonic transit of carmine red dye, reducing the time taken for its excretion. Following intraduodenal dosing to anesthetized rats, TD$8954(0.03-10 \mathrm{mg} / \mathrm{kg})$ evoked a dose-dependent relaxation of the esophagus. Following oral administration to conscious dogs, TD-8954 (10 and $30 \mu \mathrm{g} / \mathrm{kg}$ ) produced an increase in contractility of the antrum, duodenum, and jejunum. In a single ascending oral dose study in healthy human subjects, TD-8954 $(0.1-20 \mathrm{mg})$ increased bowel movement frequency and reduced the time to first stool. It is concluded that TD-8954 is a potent and selective $5-\mathrm{HT}_{4}$ receptor agonist in vitro, with robust in vivo stimulatory activity in the gastrointestinal (GI) tract of guinea pigs, rats, dogs, and humans. TD-8954 may have clinical utility in patients with disorders of reduced GI motility.

Keywords: constipation, serotonin, 5- $\mathrm{HT}_{4}$, prokinetic, TD-8954

\section{INTRODUCTION}

5-Hydroxytryptamine (5-HT) plays a critical role in coordinating gastrointestinal (GI) transit (Hansen and Skadhauge, 1997; Grider et al., 1998; Jin et al., 1999; Baker, 2005). In response to intestinal stretching and mucosal stimulation, 5-HT is released from enterochromaffin cells of the mucosal epithelium, and promotes peristalsis via activation of intrinsic primary afferent neurons located in the submucous plexus (Kirchgessner et al., 1992; FoxxOrenstein et al., 1995; Gershon and Tack, 2007). Of the 5-HT receptors believed to influence GI motility (e.g., $5-\mathrm{HT}_{1 \mathrm{~A}}, 5-\mathrm{HT}_{2 \mathrm{~A}}$, $5-\mathrm{HT}_{2 \mathrm{~B}}, 5-\mathrm{HT}_{3}$, and $5-\mathrm{HT}_{4}$; Beattie and Smith, 2008), the 5$\mathrm{HT}_{4}$ receptor subtype is considered particularly important, both physiologically and pathophysiologically (Kadowaki et al., 1996; Kim and Camilleri, 2000; Baker, 2005). The peristaltic reflex, for example, is dependent on activation of $5-\mathrm{HT}_{4}$ receptors on intrinsic primary afferent neurons, interneurons, and motor neurons within the gut wall, which results in the coordinated release of acetylcholine, substance $\mathrm{P}$, and calcitonin gene-related peptide. The release of these agents is associated with synchronized contraction and relaxation of GI smooth muscle, and propulsion of luminal contents (Jin et al., 1999; Gershon and Tack, 2007). Additionally, activation of 5- $\mathrm{HT}_{4}$ receptors in the smooth muscle of the human distal colon, and on enteric neurons or enterocytes promotes a direct relaxant effect and fluid secretion, respectively, further supporting GI transit (Hillier et al., 1994; Hansen and Skadhauge, 1997).

Agents interacting with $5-\mathrm{HT}_{3}$ and $5-\mathrm{HT}_{4}$ receptors have provided meaningful benefit to patients with GI functional disorders (Sanger, 2008). The GI prokinetic activity of $5-\mathrm{HT}_{4}$ receptor agonists, such as tegaserod (Zelnorm $\left.{ }^{\circledR}\right)$, cisapride (Propulsid ${ }^{\circledR}$ ), velusetrag (TD-5108), prucalopride (Resolor ${ }^{\circledR}$ ), and mosapride has been demonstrated in a variety of species (Jin et al., 1999; Briejer et al., 2001b; Inui et al., 2002; Ji et al., 2003; Manini et al., 2009), and clinical efficacy has been established in patients with irritable bowel syndrome with constipation (IBS-C), chronic idiopathic constipation, functional dyspepsia, or gastroparesis (Deruyttere et al., 1987; Muller-Lissner, 1987; Abell et al., 1991; Camilleri, 2001; Johanson, 2004; Patel et al., 2004; Camilleri et al., 2008; Goldberg et al., 2010). Cisapride and tegaserod were used widely to treat upper and lower GI disorders of reduced motility, respectively, although their clinical efficacy in many patients was modest (Kellow et al., 1995; Evans et al., 2004), possibly reflecting their interactions with receptors other than the $5-\mathrm{HT}_{4}$ subtype (Briejer et al., 1995; Beattie et al., 2004; Beattie and Smith, 2008; De Maeyer et al., 2008). The clinical use of cisapride and tegaserod is now restricted on the basis of cardiovascular safety concerns 
(Barbey et al., 2002; Pasricha, 2007). Cisapride was associated with serious cardiac arrhythmias including ventricular tachycardia, ventricular fibrillation, and torsades de pointes as a result of its potent cardiac human ether-à-go-go-related gene (hERG) potassium channel inhibitory activity (Mohammad et al., 1997). The marketing of tegaserod was suspended in the United States due to concerns of an increased risk of serious ischemic cardiovascular events, although two recent epidemiological studies failed to identify such an association (Anderson et al., 2009; Loughlin et al., 2010). The newer generation, highly selective $5-\mathrm{HT}_{4}$ receptor agonists, velusetrag and prucalopride, produce robust clinical efficacy in chronic idiopathic constipation patients, have been well tolerated to date, and offer renewed hope for patients experiencing disorders of reduced GI motility (Camilleri et al., 2008; Sanger, 2009; Goldberg et al., 2010; Manabe et al., 2010). Prucalopride is approved in Europe for the treatment of women with chronic idiopathic constipation who have not responded adequately to laxatives.

In this study, the in vitro and in vivo pharmacodynamic properties of a structurally novel $5-\mathrm{HT}_{4}$ receptor agonist, TD-8954 (4-\{(4-[(2-isopropyl-1H-benzoimidazole4-carbonyl)amino] methyl - piperidin-1-ylmethyl)piperidine-1carboxylic acid methyl ester; Figure 1), have been investigated. The preclinical activity of several standard $5-\mathrm{HT}_{4}$ agonists was evaluated in parallel for comparison to that of TD-8954.

\section{MATERIALS AND METHODS}

All animal experiments were conducted in accordance with the principles of good laboratory animal care provided by the Institutional Animal Care and Use Committees of Theravance, Inc. (rodent studies) or Drug Research Laboratories (dog study). The study protocol and consent form for the human single ascending dose study were reviewed by the clinical site's Institutional Review Board, and each volunteer provided written informed consent prior to initiation of study procedures. The study was conducted at a single site in accordance with the United States Code of Federal Regulations and the principles of the Declaration of Helsinki.

\section{HUMAN RECOMBINANT 5-HT 4 RECEPTORS Radioligand binding}

Radioligand binding studies were conducted as described previously (Smith et al., 2008). Inhibition of $\left[{ }^{3} \mathrm{H}\right]-\mathrm{GR} 113808$ binding was measured using membranes prepared from HEK293 cells stably expressing the human $5-\mathrm{HT}_{4(\mathrm{c})}\left(\mathrm{h} 5-\mathrm{HT}_{4(\mathrm{c})}\right)$ receptor splice variant (HEK293-h5-HT H(c) ) (Kaumann and Levy, 2006).

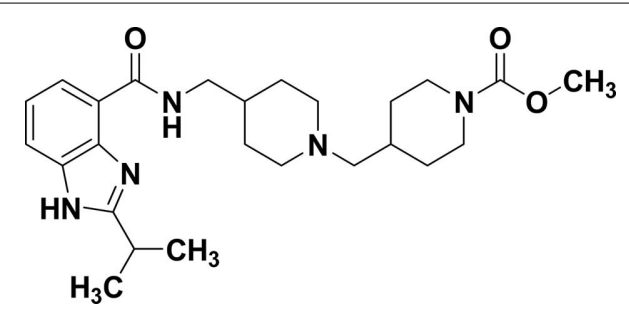

FIGURE 1 |TD-8954 (4-(4-\{[(2-isopropyl-1H-benzoimidazole-4carbonyl)amino]methyl\}-piperidin-1-ylmethyl)piperidine-1-carboxylic acid methyl ester).
5- $\mathrm{HT}_{4(\mathrm{c})}$ receptor mRNA was been detected in human GI tissue by RT-PCR (Blondel et al., 1998; Bender et al., 2000; Medhurst et al., 2001; Ito et al., 2003), and the rank order of affinities or potencies for several agonist and antagonists is maintained across $5-\mathrm{HT}_{4}$ receptor splice variants in published reports (Blondel et al., 1998; Smith et al., 2008), supporting the use of the 5-HT 4 (c) variant for the current studies. Unlabeled compound (10 pM to $100 \mu \mathrm{M})$ was incubated for $1 \mathrm{~h}$ at room temperature with [ $\left.{ }^{3} \mathrm{H}\right]-\mathrm{GR} 113808$ $(0.15 \mathrm{nM})$ and $\mathrm{h} 5-\mathrm{HT}_{4(\mathrm{c})}$ membranes $(2 \mu \mathrm{g}$ protein $)$ in a total assay volume of $400 \mu \mathrm{L}$. Binding reactions were terminated by rapid filtration over GF/B filter plates and bound radioactivity quantitated by liquid scintillation spectroscopy in Microscint20 using a TopCount Scintillation Counter (Packard BioScience, Meriden, CT, USA).

Binding data were analyzed by non-linear regression analysis using GraphPad Prism ${ }^{\mathrm{TM}}$ software (GraphPad Software, Inc., San Diego, CA, USA) and a three-parameter model for one-site competition. The $\mathrm{pK}_{\mathrm{i}}$ (negative decadic logarithm of $\mathrm{K}_{\mathrm{i}}$ ) values for test compounds were calculated from the best-fit $\mathrm{IC}_{50}$ values, and the $\mathrm{K}_{\mathrm{d}}$ value of the radioligand, using the Cheng-Prusoff equation [Cheng and Prusoff, 1973; $\mathrm{K}_{\mathrm{i}}=\mathrm{IC}_{50} /\left(1+[\mathrm{L}] / \mathrm{K}_{\mathrm{d}}\right)$ where $[\mathrm{L}]=$ radioligand concentration], and are reported as the mean \pm SEM. Standard compounds were evaluated in parallel with TD-8954; the $\mathrm{pK}_{\mathrm{i}}$ values were consistent with those reported previously (Vickery et al., 2007; Smith et al., 2008).

\section{Whole cell cAMP accumulation}

Whole cell cAMP accumulation assays were performed as described previously (Smith et al., 2008) using a homogeneous radioimmunoassay (Flashplate Adenylyl Cyclase Activation Assay System; Perkin Elmer Life Sciences, Boston, MA, USA). HEK293h5- $\mathrm{HT}_{4(\mathrm{c})}$ cells were lifted in Versene and collected by centrifugation $(1,200 \times g, 5 \mathrm{~min})$ in phosphate-buffered saline (PBS). The cell pellet was resuspended gently in warm "stimulation buffer" (provided in the assay kit) and diluted to $5 \times 10^{5}$ cells $/ \mathrm{mL}$. Cells $(25,000$ per well) were incubated with test compound $(10 \mathrm{pM}$ to $100 \mu \mathrm{M}$ ) for $15 \mathrm{~min}$ at $37^{\circ} \mathrm{C}$ in a 96-well Flashplate, in a total volume of $0.1 \mathrm{~mL}$. In antagonist inhibition studies, cells were preincubated in the absence or presence of GR113808 (0.6, 1.7, or $5 \mathrm{nM}$ ) for $20 \mathrm{~min}$ at $37^{\circ} \mathrm{C}$ prior to the addition of the test agonist. After the incubation period, $\left[{ }^{125} \mathrm{I}\right]$-cAMP was added in $100^{\circ} \mu \mathrm{L}$ of ice-cold "detection buffer" to each well, according to the manufacturer's instructions. Bound radioactivity was quantified by scintillation counting and the amount of cAMP produced was extrapolated from a cAMP standard curve.

Data were analyzed by non-linear regression analysis with GraphPad Prism ${ }^{\mathrm{TM}}$ using the three-parameter sigmoidal concentration-effect model (slope constrained to unity). The potency of test agents was reported as a mean $( \pm S E M)$ pEC $_{50}$ value (negative decadic logarithm of the effective concentration producing $50 \%$ of the maximum response), and the intrinsic activity (IA) as a mean ( \pm SEM) percentage of the maximum 5-HT-evoked response. The $\mathrm{pEC}_{50}$ and IA values for standard compounds (tested in parallel with TD-8954) were consistent with those reported previously (Vickery et al., 2007; Smith et al., 2008). Schild regression analysis was used to determine $\mathrm{pK}_{\mathrm{b}}$ values for GR113808 in the antagonist inhibition studies for 5-HT and TD8954 (Kenakin, 1997). Concentration ratios (CR) were calculated 
as the ratio of the $\mathrm{EC}_{50}$ values in the presence and absence of antagonist. The log[CR-1] was plotted against the log[GR113808], resulting in a linear relationship with the slope not significantly different from unity. The slope was therefore constrained to unity, and the X-intercept was extrapolated to provide a measure of the $\mathrm{pK}_{\mathrm{b}}$ value for GR113808.

\section{5-HT 4 receptor selectivity}

Off-target selectivity screening was conducted at Theravance, Inc. or at a contract research organization (CEREP, Paris, France). Conventional radioligand binding studies were conducted using, in the majority of assays, membranes prepared from cell lines transfected with the respective human recombinant receptor, ion channel, or transporter. The percent inhibition of specific binding by TD-8954, at a single concentration $(1 \mu \mathrm{M}$, in duplicate), was determined. Conventional whole cell voltage-clamp techniques were used to examine the interaction of TD-8954 $(3 \mu \mathrm{M})$ with neuronal (rat $\mathrm{Na}_{\mathrm{v}} 1.2$ ) and cardiac (human $\mathrm{Na}_{\mathrm{v}} 1.5$ ) voltage-gated sodium channels and hERG potassium channels (see Smith et al., 2006, 2008).

\section{Functional 5-HT, receptor activity in the guinea pig colonic longitudinal muscle/myenteric plexus}

Adult, male Dunkin Hartley guinea pigs (200-350 g, Harlan, Chicago, IL, USA) were euthanized by $\mathrm{CO}_{2}$ asphyxiation. The distal colon was removed and placed in Krebs-Henseleit physiological buffer containing (in $\mathrm{mM}$ ): $\mathrm{KCl}$ (4.7), $\mathrm{KH}_{2} \mathrm{PO}_{4}$ (1.2), $\mathrm{MgSO}_{4}$ anhydrous (1.2), $\mathrm{NaCl}$ (118.1), D-glucose (11.1), $\mathrm{NaHCO}_{3}$ (25.0), $\mathrm{CaCl}_{2}$ (2.6), ondansetron (0.003; to block 5- $\mathrm{HT}_{3}$ receptors), methysergide (0.001; to antagonize $5-\mathrm{HT}_{1}$ and $5-\mathrm{HT}_{2}$ receptors), and indomethacin ( 0.001 ; to inhibit prostaglandin synthesis). The colon was cut into $5 \mathrm{~cm}$ lengths, and the longitudinal muscle/myenteric plexus (LMMP) carefully peeled off. The LMMP was then mounted, under a tension of $10 \mathrm{mN}$, in a $10-\mathrm{mL}$ tissue bath filled with Krebs-Henseleit buffer $\left(37^{\circ} \mathrm{C}\right.$, aerated continuously with $95 \% \mathrm{O}_{2} / 5 \% \mathrm{CO}_{2}$ ).

Tissues were washed three times (at 0,15 , and $30 \mathrm{~min}$ after mounting) and then challenged (at $45 \mathrm{~min}$ ) with 5 -HT at a concentration $(0.3 \mu \mathrm{M})$ previously established to evoke a maximal contractile response. Once the contraction had reached its maximum, tissues were washed four times ( $2 \mathrm{~min}$ between each wash), and once more $10 \mathrm{~min}$ later. An additional priming challenge of 5-HT $(0.3 \mu \mathrm{M})$ was made 15 min later. Following further washing prior to, and after a third 5-HT $(0.3 \mu \mathrm{M})$ challenge, a cumulative concentration-response curve to 5-HT, tegaserod, mosapride, cisapride, prucalopride, or TD-8954 was constructed. TD-8954 concentration-response curves were also constructed in tissues previously exposed for $15 \mathrm{~min}$ to the selective $5-\mathrm{HT}_{4}$ receptor antagonist, piboserod (0.3 $\mu \mathrm{M}$; Gaster et al., 1995) or vehicle. Changes in colonic isometric force were recorded by means of a force transducer (World Precision Instruments, model Fort 100), amplifier (Astro Med., model S48), and a data acquisition system (Biopac MP100, Acknowledge ${ }^{\mathrm{TM}}$ Waveform Acquisition and Analysis software). Contractile responses to test compounds were normalized to those of the last, primed 5-HT $(0.3 \mu \mathrm{M})$ response in each tissue. Data were analyzed by non-linear regression analysis with GraphPad Prism using the four-parameter sigmoidal concentration-effect model. The $\mathrm{pEC}_{50}$ and IA (i.e., the maximum compound-evoked response expressed as a percentage of the fully primed 5-HT maximum) were derived and reported for each test agent.

\section{GUINEA PIG COLONIC TRANSIT}

Adult, male Dunkin Hartley guinea pigs (220-300 g, Harlan, Chicago, IL, USA) were acclimated to their holding room (temperature controlled at $21 \pm 1^{\circ} \mathrm{C}$ and $12: 12 \mathrm{~h}$ light-dark cycle commencing at 7 a.m.) for approximately 1 week prior to surgery. A standard guinea pig diet (7006, Harlan Teklad) and drinking water were provided ad libitum. Guinea pigs were anesthetized with isoflurane $(2-3 \%$, in oxygen) in an induction chamber. Maintenance of anesthesia was achieved with isoflurane (2-3\%) administered via a nose cone. The mid-scapular area and abdomen were shaved and cleansed with betadine and 70\% isopropanol. A small incision was made in the lower abdomen to expose the proximal colon. After isolation, a small incision was made in the proximal colon (approximately $2 \mathrm{~cm}$ from the cecum) and a cannula consisting of micro-renathane (MRE-040) tubing with a $2-\mathrm{cm}$ silicone rubber tip (RenaSil ${ }^{\mathrm{TM}}$; $0.047^{\prime \prime} \mathrm{OD} \times 0.025^{\prime \prime}$ ID) was introduced and advanced approximately $2 \mathrm{~cm}$ toward the aboral end. A purse-string suture (Ethicon, 6-0 silk) was used to anchor the cannula in the colon and Baytril antibiotic $(2.27 \%)$ was then applied topically to the colonic surgical site. The muscle layer was closed with a 4-0 Vicryl suture. The cannula was then secured to the nearby musculature with a 6-0 silk suture, tunneled under the skin and exteriorized at the midscapular region. The cannula was flushed and locked with sterile saline (Baxter), sealed with a sterile stainless steel pin, and secured to the back of the neck with a wound clip. The incisions in the peritoneum and abdomen were cleansed of blood and closed with a 3-0 Ethilon suture (Ethicon). Subcutaneous (s.c.) warmed lactated-Ringer's solution $(3 \mathrm{~mL})$ was administered immediately after surgery in addition to an intramuscular injection of the opioid analgesic, Buprenex ${ }^{\circledR}$ (buprenorphine, $0.03 \mathrm{mg} / \mathrm{kg}$ ).

At least 5 days after surgery, guinea pigs were assigned randomly to a study group. Animals were dosed with test agent or vehicle ( $2 \mathrm{~mL} / \mathrm{kg} \mathrm{s.c.)}$, and $5 \mathrm{~min}$ later, each guinea pig was gently restrained and a non-absorbable marker $(0.2 \mathrm{~mL})$ was infused into the proximal colon via the implanted cannula. The marker consisted of $6 \mathrm{~g}$ of carmine red dye per $15 \mathrm{~mL}$ of carboxymethyl cellulose $(0.5 \%)$. The study personnel were blinded to the treatment that each animal received. Animal cages were visually inspected for the presence of excreted red fecal pellets at 30-min intervals until each guinea pig had excreted pellets containing the red marker, or until $10 \mathrm{~h}$ had lapsed from the time of the marker injection. In the case that an animal failed to produce red fecal pellets within $10 \mathrm{~h}$, the animal was left overnight in a clean cage and inspected the following morning. If excretion of dye occurred overnight, a value of $10 \mathrm{~h}$ was assigned. The whole colonic transit was defined as the time that lapsed between marker injection and the appearance of dye in the feces. Data for each treatment group were expressed as a mean percent increase $( \pm$ SEM $)$ in colonic transit time relative to vehicle-treated animals. Differences between treatment groups were determined using one-way analysis of variance 
(ANOVA) with a Dunnett's post hoc test $(p<0.05$ considered to be statistically significant).

\section{RAT ESOPHAGEAL RELAXATION}

The technique of digital sonomicrometry was used (Adelson and Million, 2004; Armstrong et al., 2006). Adult, male SpragueDawley rats (250-350 g, Harlan, Chicago, IL, USA) were acclimated to the colony room (temperature controlled at $21 \pm 1^{\circ} \mathrm{C}$ and 12:12 h light-dark cycle commencing at 7 a.m.) for at least 5 days prior to investigation. Standard rat diet (Harlan Teklad) and drinking water were available ad libitum. Rats were anesthetized with isoflurane $(2-3 \%)$ in an induction chamber and anesthesia was then maintained with isoflurane (2-3\%) via a nose cone for the duration of each experiment. Animals were placed, in a supine position, on a heated pad to maintain body temperature at $37-38^{\circ} \mathrm{C}$ [monitored rectally with a sensor (Physitemp BAT12)]. A midline incision was made in the skin and muscle layers of the abdomen, and the stomach and esophagus were exposed. A small incision was made in the upper duodenum approximately $1 \mathrm{~cm}$ from the pyloric sphincter, to permit intraduodenal (i.d.) administration of test agents. A micro-renathane catheter (MRE40 with a $1 \mathrm{~cm}$ RenaSil rubber tip) was inserted approximately $1.5 \mathrm{~cm}$ into the duodenum via the incision and closed with 6-0 silk purse-string suture. Two piezoelectric crystals $(1 \mathrm{~mm}$ diameter; Sonometrics Corp.) were gently glued, in a longitudinal orientation, to the distal esophagus $(1 \mathrm{~cm}$ from the lower esophageal sphincter) using Vetbond tissue adhesive. The inter-crystal distance was approximately $2 \mathrm{~mm}$. The wires connecting the crystals to the measurement device (Sonometrics Corp. TRX series 8) were exteriorized through the abdominal incision site, which was then closed with 4-0 Ethilon suture.

Following surgery, baseline esophageal tone was allowed to stabilize over approximately $30 \mathrm{~min}$, prior to drug administration. The settings for the Sonometrics system were fixed within the Sonoview software (Sonometrics Corp., version 3.2.1) as follows: sampling rate $=99.4 \mathrm{~Hz}$, transmit pulse $=375 \mathrm{~ns}$, inhibit delay $=1.2-1.5 \mathrm{~mm}$, velocity of sound through biological tissue $=1.59 \mathrm{~mm} / \mu \mathrm{s}$. Drug vehicle, followed by increasing doses of test compounds $(0.5 \mathrm{~mL} / \mathrm{kg})$ were administered cumulatively via the duodenal cannula. Each dose was administered only when the esophageal response to the preceding dose had reached a maximum (typically 15-20 min). Changes in inter-crystal distance (in $\mathrm{mm}$ ) from resting levels were averaged for each treatment group. The data were fitted to a sigmoidal dose-response relationship with variable slope, and an $\mathrm{ED}_{50}$ value (i.e., the dose resulting in $50 \%$ of the maximum response) was calculated using Prism graphics software 3.0 (GraphPad, Inc.).

\section{DOG GASTROINTESTINAL CONTRACTILITY}

Five adult, female beagle dogs (6.5-8.5 kg, Marshall BioResources, North Rose, NY, USA), were maintained in a temperature controlled holding room at $21-24^{\circ} \mathrm{C}$ and $12: 12 \mathrm{~h}$ light-dark cycle commencing at 7 a.m. for at least 7 days prior to surgery. Dogs were fed at 8 a.m. and 6 p.m. with commercial dog food, while water was available ad libitum. Under pentobarbital anesthesia $(30 \mathrm{mg} / \mathrm{kg}$ i.v. for induction, $1-2 \mathrm{mg} / \mathrm{kg}$ i.v. for maintenance), a strain gauge transducer (R. B. Products, Stillwater, MN, USA, calibrated with weights of 10-200 g) was sutured on to the antrum of the stomach ( $1 \mathrm{~cm}$ above the pylorus), duodenum, and jejunum $(10-12 \mathrm{~cm}$ distal to the ligament of Treitz). Strain gauges were positioned to record circular muscle activity (Bass and Wiley, 1972). The strain gauge wiring was anchored securely to abdominal muscle with four stainless steel sutures. The abdominal incision was then closed around the wiring assembly. All dogs were treated with a fentanyl $(25 \mu \mathrm{g})$ patch, which was applied 1 day prior to surgery and removed 3-4 days post-surgery. At least 2 weeks were allowed to lapse after surgery, before testing.

Dogs were fasted for $18 \mathrm{~h}$ prior to each study. The animals were positioned in slings, and the strain gauges were connected to a Grass (model 7P) polygraph to allow recording of the GI motility patterns. In fasted beagles, three phases of activity are evident in the antrum, duodenum and jejunum: quiescence followed by a pre-burst and then a burst period. After recording data for a full motility cycle, and confirming commencement of a quiescent period, each dog was dosed orally with TD-8954 (0.01 and $0.03 \mathrm{mg} / \mathrm{kg})$, tegaserod $(0.1$ and $0.3 \mathrm{mg} / \mathrm{kg})$, or vehicle $(1 \mathrm{~mL} / \mathrm{kg}$ over $5 \mathrm{~s}$ ), followed by a $10 \mathrm{~mL}$ flush of water. After dosing, GI motility was monitored for $3 \mathrm{~h}$. Dogs were allowed at least 4 days between treatments, the sequence of which was based on a Latin square design.

The area under the contractile force-time curve (AUC) of GI muscle contractions was measured directly from the polygraph tracings by means of a Numonics ${ }^{\mathrm{TM}} 2210$ digitizing tablet in conjunction with an IBM 80486 computer and Sigma Scan ${ }^{\mathrm{TM}}$ analysis software (Jandel Scientific). Data were expressed as mean values $( \pm$ SEM) for each treatment group.

\section{HUMAN SINGLE ASCENDING DOSE STUDY}

A Phase 1, double-blind, randomized, placebo-controlled, single ascending dose study was performed, consisting of seven sequential cohorts. In each cohort, eight healthy male and female subjects (18-50 years old) were randomized such that six subjects received a single oral dose of TD-8954 $(0.1,0.5,1,2,5,10$, or $20 \mathrm{mg})$ and two subjects received placebo. The lowest dose of TD-8954 was formulated as an aqueous solution, while the other doses were administered as a powder in capsule. All subjects were confined to the clinical research unit from day 1 (admission) until after the 48-h post-dose safety assessments, and then returned on day 7 for a follow-up visit. A bowel diary was used to record the date and time of each bowel movement after dosing. The bowel diary was reviewed daily and before discharge. Blood samples were collected to assess the pharmacokinetics of TD-8954, and safety and tolerability were closely monitored.

\section{MATERIALS}

Standard biochemical and tissue culture reagents were purchased from Sigma-Aldrich (St Louis, MO, USA) and Invitrogen (Carlsbad, CA, USA) respectively. $\left[{ }^{3} \mathrm{H}\right] \mathrm{GR} 113808$ was purchased from Amersham Biosciences (Newark, NJ, USA). The Flashplate Adenylyl Cyclase Activation Assay System was purchased from PerkinElmer (Boston, MA, USA). TD-8954, prucalopride, mosapride, and piboserod were synthesized at Theravance, Inc. GR113808, tegaserod and cisapride were purchased from Tocris Cookson (Ellisville, MO, USA), Apin Chemicals (Abingdon, Oxon, UK) and 
Sequoia Research Products (Pangbourne, UK), respectively. Carbachol, 5-HT, and ketanserin were purchased from Sigma-Aldrich. For in vitro radioligand binding and cAMP accumulation studies, stock agonist solutions $(10 \mathrm{mM})$ were prepared in DMSO, diluted to $400 \mu \mathrm{M}$ with $50 \mathrm{mM}$ HEPES (pH 7.4) at $25^{\circ} \mathrm{C}$, containing $0.1 \%$ $\mathrm{BSA}$, and serial dilutions prepared in the same buffer. For isolated tissue studies, $10 \mathrm{mM}$ solutions, prepared in DMSO, were diluted serially in sterile water. For in vivo studies, TD-8954 and prucalopride were dissolved in 5\% dextrose in distilled water (D5W) or $0.9 \%$ saline, while tegaserod and mosapride were prepared in $10 \%$ sulfobutyl ether-beta cyclodextrin (10\% SBE/CD), and cisapride was dissolved in 10\% SBE/CD containing citrate $(20 \mathrm{mM})$. Doses were expressed with respect to the free base weights of each compound.

\section{RESULTS}

\section{5-HT 4 RECEPTOR BINDING AND cAMP ACCUMULATION}

TD-8954, tegaserod, prucalopride, cisapride, and mosapride produced a concentration-dependent inhibition of $\left[{ }^{3} \mathrm{H}\right]-\mathrm{GR} 113808$ binding to HEK293-h5-HT 4 (c) cell membranes. Comparison of the mean $\mathrm{pK}_{\mathrm{i}}$ values for the compounds (Table 1) indicated a rank order of affinity of TD-8954 $\left(\mathrm{pK}_{\mathrm{i}}=9.4\right)>$ tegaserod $\left(\mathrm{pK}_{\mathrm{i}}=8.6\right)>$ prucalopride $\left(\mathrm{pK}_{\mathrm{i}}=7.6\right)>$ cisapride $\left(\mathrm{pK}_{\mathrm{i}}=7.1\right)>$ mosapride $\left(\mathrm{pK}_{\mathrm{i}}=6.8\right)$. In cAMP accumulation assays, using HEK-293 cells stably transfected with the h5-HT $4(\mathrm{c})$ receptor, TD-8954, tegaserod, cisapride, prucalopride, and mosapride produced a concentration-dependent increase in cAMP. The rank order of potency was TD-8954 $\left(\mathrm{pEC}_{50}=9.3\right)>$ tegaserod $\left(\mathrm{pEC}_{50}=8.7\right)>$ prucalopride $\left(\mathrm{pEC}_{50}=7.9\right)>$ cisapride $\left(\mathrm{pEC}_{50}=\right.$ $7.4)>$ mosapride $\left(\mathrm{pEC}_{50}=6.3\right)$. The mean IAs of TD-8954, tegaserod, cisapride, prucalopride, and mosapride, relative to 5HT (100\%) were 83, 120, 101, 109, and 22\%, respectively; Table 1). In antagonist inhibition studies, increasing concentrations of GR113808 produced rightward shifts in the 5-HT and TD-8954 concentration-response curves, resulting in $\mathrm{pK}_{\mathrm{b}}$ values (with $95 \%$ confidence intervals) of 10.3 (95\% CI: 10.2-10.4) and 10.3 (95\% CI: 10.2-10.5), respectively.

\section{5-HT 4 RECEPTOR SELECTIVITY}

TD-8954 was $>2,000$-fold selective for $\mathrm{h} 5-\mathrm{HT}_{4(\mathrm{c})}$ receptors over other 5-HT receptors (Table 2), and all non-5-HT receptors, transporters, ion channels, and enzymes tested (Table 3). TD$8954(3 \mu \mathrm{M})$ had no effect on hERG potassium currents $(n=6$ cells) while cisapride $(20 \mathrm{nM})$ was associated with a mean inhibition of $65 \%$ in the same cells. Exposure to TD-8954 $(3 \mu \mathrm{M})$ for 3 min had no effect on the magnitude of the inward rat $\mathrm{Na}_{\mathrm{v}} 1.2 \mathrm{a}$ or human $\mathrm{Na}_{\mathrm{v}} 1.5$ sodium currents ( $n=3$ cells for each).

\section{GUINEA PIG COLONIC LONGITUDINAL MUSCLE/MYENTERIC PLEXUS}

TD-8954, tegaserod, cisapride, prucalopride, and mosapride produced concentration-dependent contraction of the guinea pig colonic LMMP (Figure 2). Comparison of the mean $\mathrm{pEC}_{50}( \pm \mathrm{SEM})$ values for the compounds indicated a rank order of potency of TD-8954 $\left(\mathrm{pEC}_{50}=8.6\right)>$ tegaserod $\left(\mathrm{pEC}_{50}=7.9\right)=$ prucalopride $\left(\mathrm{pEC}_{50}=7.7\right)>$ cisapride $\left(\mathrm{pEC}_{50}=\right.$ $7.0)>$ mosapride $\left(\mathrm{pEC}_{50}=5.4\right)$. TD-8954 had a mean IA $(55 \%$ of the 5-HT maximum) lower than that of cisapride and prucalopride (75 and $81 \%$, respectively), but higher than that of tegaserod (45\%) and mosapride (37\%; Table 1). Incubation of tissues with the selective $5-\mathrm{HT}_{4}$ receptor antagonist, piboserod $(0.3 \mu \mathrm{M})$, resulted in a 614-fold shift (apparent $\mathrm{pK}_{\mathrm{b}}$ value $=9.3$ ) of the TD-8954 concentration-response curve (data not shown).

Table 2 | Binding affinity $\left(\mathrm{pK}_{\mathrm{i}}\right)$ of TD-8954 at 5-HT receptor subtypes.

\begin{tabular}{|c|c|c|c|}
\hline Receptor & Radioligand & [Radioligand] (nM) & $\mathbf{p K _ { \mathbf { i } }}$ \\
\hline Human $5-\mathrm{HT}_{1 \mathrm{~A}}$ & {$\left[{ }^{3} \mathrm{H}\right]-8-\mathrm{OH}-\mathrm{DPAT}$} & 0.5 & $<6$ \\
\hline Rat $5-\mathrm{HT}_{1 \mathrm{~B}}$ & {$\left[{ }^{125} \mid\right]-C Y P$} & 0.1 & $<6$ \\
\hline Bovine $5-\mathrm{HT}_{1 \mathrm{D}}$ & {$\left[{ }^{3} \mathrm{H}\right]$-serotonin } & 2 & $<6$ \\
\hline Human $5-\mathrm{HT}_{2 \mathrm{~A}}$ & {$\left[{ }^{3} \mathrm{H}\right]-$ ketanserin } & 0.5 & $<6$ \\
\hline Human $5-\mathrm{HT}_{2 \mathrm{~B}}$ & {$\left[{ }^{3} \mathrm{H}\right]-\mathrm{LSD}$} & 1.2 & $<6$ \\
\hline Human $5-\mathrm{HT}_{2 \mathrm{C}}$ & {$\left[{ }^{3} \mathrm{H}\right]-$ mesulergine } & 1 & $<6$ \\
\hline Human 5- $\mathrm{HT}_{3 a}$ & {$\left[{ }^{3} \mathrm{H}\right]-\mathrm{GR} 65630$} & 0.5 & $<4$ \\
\hline Human $5-\mathrm{HT}_{4(\mathrm{c})}$ & {$\left[{ }^{3} \mathrm{H}\right]-\mathrm{GR} 113808$} & 0.15 & 9.4 \\
\hline Human $5-\mathrm{HT}_{5 \mathrm{a}}$ & {$\left[{ }^{3} \mathrm{H}\right]-\mathrm{LSD}$} & 1 & $<6$ \\
\hline Human $5-\mathrm{HT}_{6}$ & {$\left[{ }^{3} \mathrm{H}\right]-\mathrm{LSD}$} & 2 & $<6$ \\
\hline Human $5-\mathrm{HT}_{7}$ & {$\left[{ }^{3} \mathrm{H}\right]-\mathrm{LSD}$} & 4 & $<6$ \\
\hline
\end{tabular}

Inhibition of radioligand binding to non-5-HT receptor subtypes was determined in duplicate at a single test concentration $\left(1 \mu \mathrm{M}\right.$, with the exception of the $5-\mathrm{HT}_{3 a}$ receptor subtype, at which concentrations up to $100 \mu \mathrm{M}$ were evaluated).

Table 1 | Human 5-HT $4(\mathrm{c})$ binding affinity (HEK293-h5- $\mathrm{HT}_{4(\mathrm{c})} ; \mathrm{pK}_{\mathrm{i}}$ ), and human (HEK293-h5-HT $4(\mathrm{c})$ ) and guinea pig colonic longitudinal muscle/myenteric plexus (LMMP) agonist potency $\left(\mathrm{pEC}_{50}\right)$ and intrinsic activity (IA; \% 5-HT maximum) values for TD-8954, cisapride, mosapride, prucalopride, and tegaserod.

\begin{tabular}{|c|c|c|c|c|c|c|c|c|}
\hline & \multicolumn{2}{|c|}{$\begin{array}{l}\text { Human } 5-\mathrm{HT}_{4(\mathrm{c})} \\
\text { receptor affinity }\end{array}$} & \multicolumn{3}{|c|}{$\begin{array}{l}\text { Human } 5-\mathrm{HT}_{4(\mathrm{c})} \\
\text { agonist activity }\end{array}$} & \multicolumn{2}{|c|}{$\begin{array}{l}\text { Guinea pig colonic LMMP } \\
\text { contractile activity }\end{array}$} & \multirow[b]{2}{*}{$n$} \\
\hline & $\begin{array}{l}\mathbf{p K}_{\mathbf{i}} \\
(\text { mean } \pm \text { SEM })\end{array}$ & $n$ & $\begin{array}{l}\mathrm{pEC}_{50} \\
(\text { mean } \pm \text { SEM) }\end{array}$ & $\begin{array}{l}\text { IA (mean \% 5-HT } \\
\max \pm \text { SEM) }\end{array}$ & $n$ & $\begin{array}{l}\mathrm{pEC}_{50} \\
(\text { mean } \pm \mathrm{SEM})\end{array}$ & $\begin{array}{l}\text { IA (mean \% 5-HT } \\
\max \pm \text { SEM) }\end{array}$ & \\
\hline TD-8954 & $9.4 \pm 0.04$ & 6 & $9.3 \pm 0.11$ & $83 \pm 6$ & 6 & $8.6 \pm 0.1$ & $55 \pm 2$ & 24 \\
\hline Cisapride & $7.1 \pm 0.05$ & 11 & $7.4 \pm 0.11$ & $101 \pm 4$ & 11 & $7.0 \pm 0.1$ & $75 \pm 3$ & 10 \\
\hline Tegaserod & $8.6 \pm 0.03$ & 11 & $8.7 \pm 0.07$ & $120 \pm 5$ & 11 & $7.9 \pm 0.3$ & $45 \pm 3$ & 13 \\
\hline
\end{tabular}


Table 3 | Binding data (\% inhibition of specific binding and $\mathrm{pK}_{\mathrm{i}}$ values) of TD-8954 at non-5-HT receptors, transporters, ion channels, and enzymes.

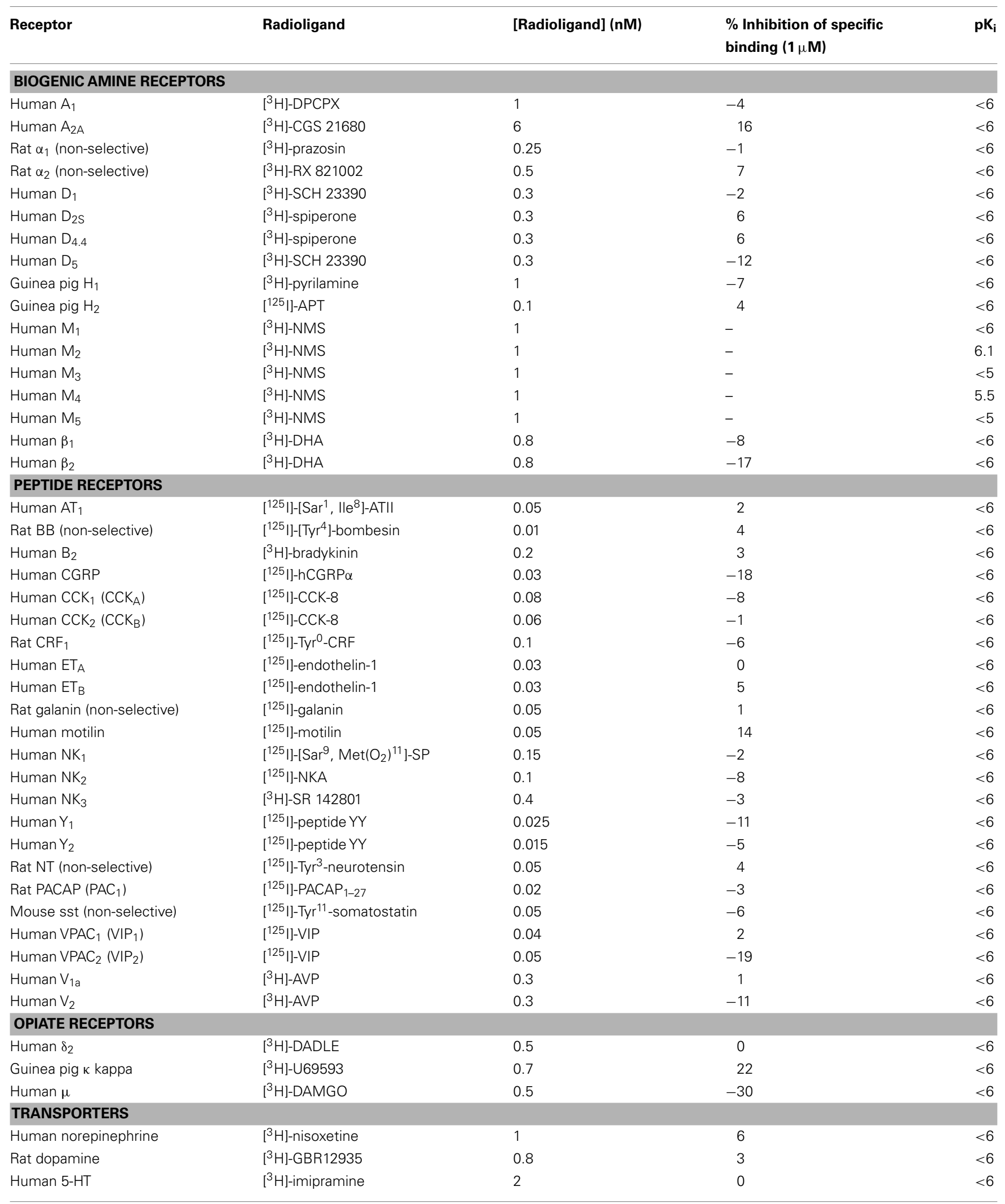


Table 3 | Continued

\begin{tabular}{|c|c|c|c|c|}
\hline Receptor & Radioligand & [Radioligand] (nM) & $\begin{array}{l}\% \text { Inhibition of specific } \\
\text { binding }(1 \mu \mathrm{M})\end{array}$ & $\mathbf{p K}_{\mathbf{i}}$ \\
\hline \multicolumn{5}{|l|}{ ION CHANNELS } \\
\hline Rat kainate & {$\left[{ }^{3} \mathrm{H}\right]-$ kainic acid } & 5 & -6 & $<6$ \\
\hline Rat NMDA & {$\left[{ }^{3} \mathrm{H}\right]-\mathrm{CGP} 39653$} & 5 & -6 & $<6$ \\
\hline Rat $\alpha_{4} \beta_{2}$ nAChR ( $\alpha$-BGTX-insensitive) & {$\left[{ }^{3} \mathrm{H}\right]$-cytisine } & 1.5 & -2 & $<6$ \\
\hline Rat $\mathrm{Ca}^{2+}$ channel (L, DHP site) & {$\left[{ }^{3} \mathrm{H}\right]-(+) P N 200-110$} & 0.04 & 7 & $<6$ \\
\hline Rat $\mathrm{Ca}^{2+}$ channel (L, diltiazem site) & {$\left[{ }^{3} \mathrm{H}\right]$-diltiazem } & 5 & 13 & $<6$ \\
\hline Rat $\mathrm{Ca}^{2+}$ channel (L, verapamil site) & {$\left[{ }^{3} \mathrm{H}\right]-(-) \mathrm{D} 888$} & 0.5 & 21 & $<6$ \\
\hline Rat $\mathrm{Ca}^{2+}$ channel (N) & {$\left[{ }^{125} \mid\right]-\omega$-conotoxin } & 0.001 & -11 & $<6$ \\
\hline $\mathrm{K}^{+}$ATP channel & {$\left[{ }^{3} \mathrm{H}\right]$-glibenclamide } & 0.1 & 5 & $<6$ \\
\hline $\mathrm{K}^{+} \vee$ channel & {$\left[{ }^{125} \mid\right]-\alpha$-dendrotoxin } & 0.01 & -5 & $<6$ \\
\hline Rat GABA (non-selective) & {$\left[{ }^{3} \mathrm{H}\right]-\mathrm{GABA}$} & 10 & -6 & $<6$ \\
\hline Rat P2Y & {$\left[{ }^{35} \mathrm{~S}\right]-\mathrm{dATP} \alpha \mathrm{S}$} & 10 & 8 & $<6$ \\
\hline Rat $\sigma$ (non-selective) & {$\left[{ }^{3} \mathrm{H}\right]-\mathrm{DTG}$} & 8 & 30 & $<6$ \\
\hline Enzyme & $\begin{array}{l}\text { Substrate/stimulus/ } \\
\text { tracer }\end{array}$ & $\begin{array}{l}\text { [Substrate/stimulus/ } \\
\text { tracer] }(\mu \mathrm{M})\end{array}$ & $\begin{array}{l}\% \text { Inhibition of } \\
\text { control }(1 \mu \mathrm{M})\end{array}$ & $\mathrm{pIC}_{50}$ \\
\hline Human $\mathrm{COX}_{1}$ & Arachidonic acid & 0.3 & 2 & $<6$ \\
\hline Human $\mathrm{COX}_{2}$ & Arachidonic acid & 50 & -36 & $<6$ \\
\hline Human PDE4 & {$\left[{ }^{3} \mathrm{H}\right]-\mathrm{cAMP}+\mathrm{cAMP}$} & 1 & -19 & $<6$ \\
\hline Rat adenylyl cyclase & ATP & 500 & 5 & $<6$ \\
\hline Human acetylcholinesterase & AMTCh & 50 & 2 & $<6$ \\
\hline
\end{tabular}

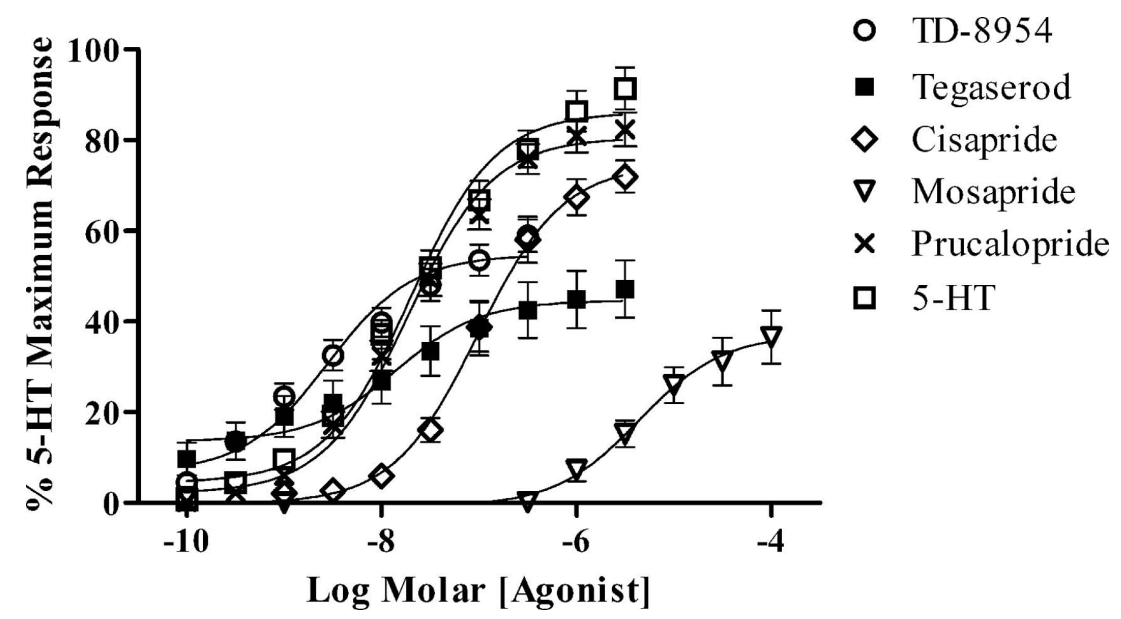

FIGURE 2 | Concentration-response curves to TD-8954 $(n=24)$, tegaserod $(n=13)$, cisapride $(n=10)$, mosapride $(n=3)$, prucalopride $(n=24)$, and 5-HT $(n=26)$ in the guinea pig isolated colonic

\section{GUINEA PIG COLONIC TRANSIT}

In vehicle ( $2 \mathrm{~mL} / \mathrm{kg}$ s.c.)-treated guinea pigs, the mean time taken for excretion of the first fecal pellet containing red dye was typically between 220 and $310 \mathrm{~min}$. Following s.c. dosing, TD8954 , tegaserod, cisapride, mosapride (each at $0.03-3 \mathrm{mg} / \mathrm{kg}$ ) and
LMMP preparation. Values are expressed as the mean ( \pm SEM) change in tension, as a percentage of the primed $5-\mathrm{HT}(0.3 \mu \mathrm{M})$ response in the same tissue.

prucalopride $(0.03-10 \mathrm{mg} / \mathrm{kg})$ increased colonic transit, reducing the time taken for excretion of the dye, compared to vehicle-treated animals (Figure 3), although statistical significance ( $p<0.05$, oneway ANOVA with a Dunnett's post hoc test) was achieved only for all of the TD-8954 doses and for the 0.3 and $3 \mathrm{mg} / \mathrm{kg}$ prucalopride 


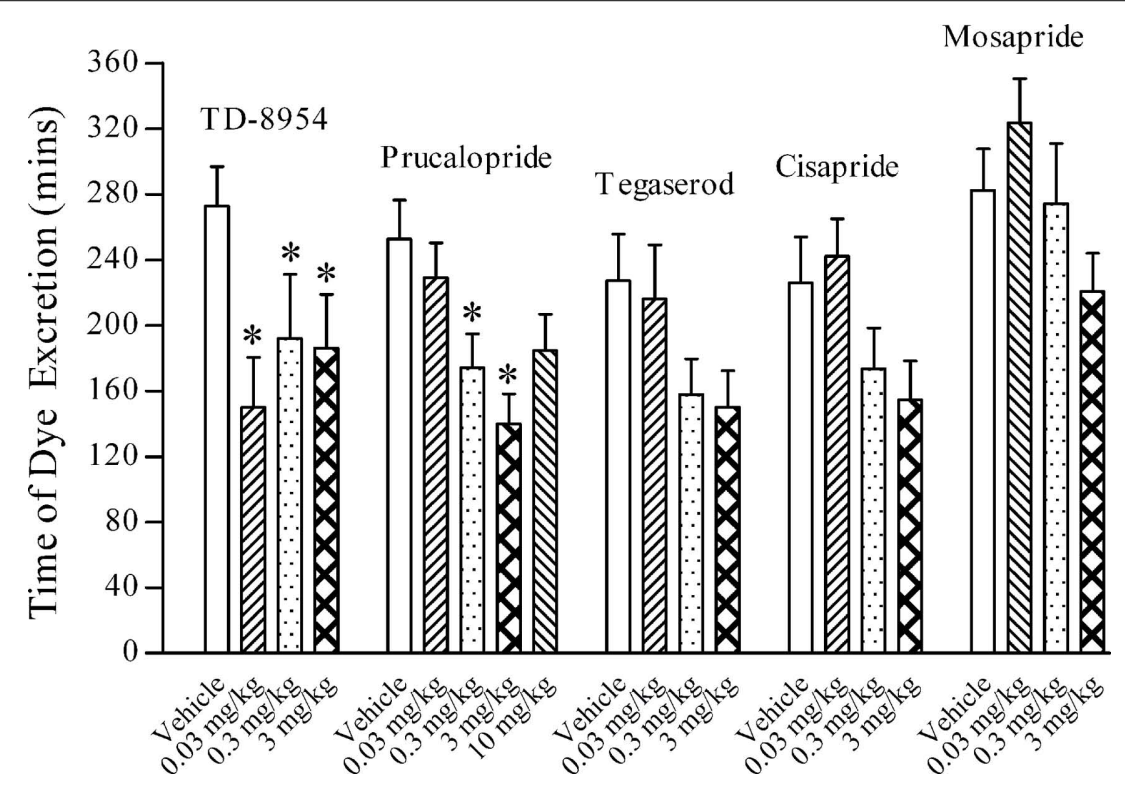

FIGURE 3 | The effects of TD-8954, tegaserod, cisapride, mosapride (each at $0.03-3 \mathrm{mg} / \mathrm{kg}), \mathrm{prucalopride}(0.03-10 \mathrm{mg} / \mathrm{kg})$, and vehicle (2 mL/ $\mathrm{kg})$, administered s.c., on the colonic transit of dye in conscious guinea pigs ( $n=9-22$ for each group; ${ }^{*} p<0.05 ;$ ANOVA followed by Dunnett's post hoc test vs. vehicle).

doses. TD-8954 was more potent than tegaserod, prucalopride, cisapride, and mosapride, being significantly active at the lowest dose tested $(0.03 \mathrm{mg} / \mathrm{kg})$. At $0.03 \mathrm{mg} / \mathrm{kg}$, TD-8954 had already achieved its maximum effect.

\section{RAT ESOPHAGEAL RELAXATION}

Following crystal placement on the rat esophagus, 30 min proved sufficient to establish a stable sonomicrometry recording. No spontaneous changes in esophageal muscle length were observed after this stabilization period. Following cumulative i.d. dosing, TD-8954, prucalopride, tegaserod (each $0.03-10 \mathrm{mg} / \mathrm{kg}$ ), cisapride $(0.3-10 \mathrm{mg} / \mathrm{kg})$, and mosapride $(0.3-10 \mathrm{mg} / \mathrm{kg})$, but not their vehicles $(1-10 \mathrm{~mL} / \mathrm{kg})$ evoked a dose-dependent increase in intercrystal distance, consistent with esophageal relaxation (Figure 4). The $\mathrm{ED}_{50}$ values (with 95\% confidence limits) for TD-8954 and prucalopride were $0.15(0.08-0.26)$ and $0.18(0.13-0.25) \mathrm{mg} / \mathrm{kg}$, respectively. Accurate $\mathrm{ED}_{50}$ values could not be calculated for tegaserod, cisapride, and mosapride as solubility limitations precluded verification that their maximum relaxations had been achieved. To compare the potencies of each compound, the doses of TD-8954, prucalopride, tegaserod, cisapride, and mosapride associated with a relaxation response of $0.1 \mathrm{~mm}$ were calculated (i.e., $0.23,0.30,2.43,2.66$, and $4.37 \mathrm{mg} / \mathrm{kg}$, respectively; Figure 4). TD-8954 was therefore equieffective, on a dose basis, with prucalopride following i.d. dosing, and 11-, 12-, and 19-fold more potent than tegaserod, cisapride, and mosapride, respectively.

\section{DOG GASTROINTESTINAL CONTRACTILITY}

The quiescent phase of the antrum, duodenum, and jejunum motility cycle generally lasted for 50-60 min before transitioning into the pre-burst period (muscle contractions of gradually increasing magnitude occurring at random, with a duration of 30-60 $\mathrm{min}$ ), followed by the burst period (vigorous and frequent contractions, with a duration of 5-15 min). Following oral administration of vehicle $(1 \mathrm{~mL} / \mathrm{kg})$, there was little or no change in the activity of the antrum, duodenum, or jejunum; the expected motility patterns characteristic of fasted beagles were maintained throughout the observation period (Figures 5 and 6). TD-8954 $(0.01$ and $0.03 \mathrm{mg} / \mathrm{kg})$ and tegaserod $(0.1$ and $0.3 \mathrm{mg} / \mathrm{kg})$ produced increases in contractility in the antrum, duodenum, and jejunum (Figure 5). The onset of contractile activity with TD8954 occurred typically within $10 \mathrm{~min}$ of dosing (Figure 6). Comparison of the activities of TD-8954 and tegaserod indicated that TD-8954 was statistically significantly more potent than tegaserod in the antrum, duodenum, and jejunum following oral administration ( $p<0.05$, ANOVA, followed by Dunnett's post hoc test).

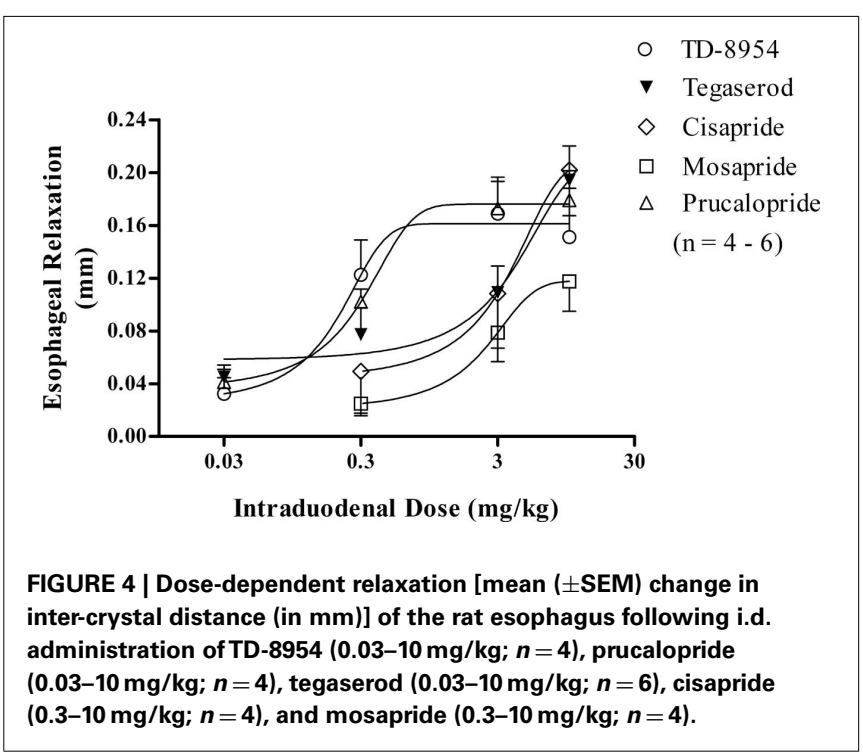




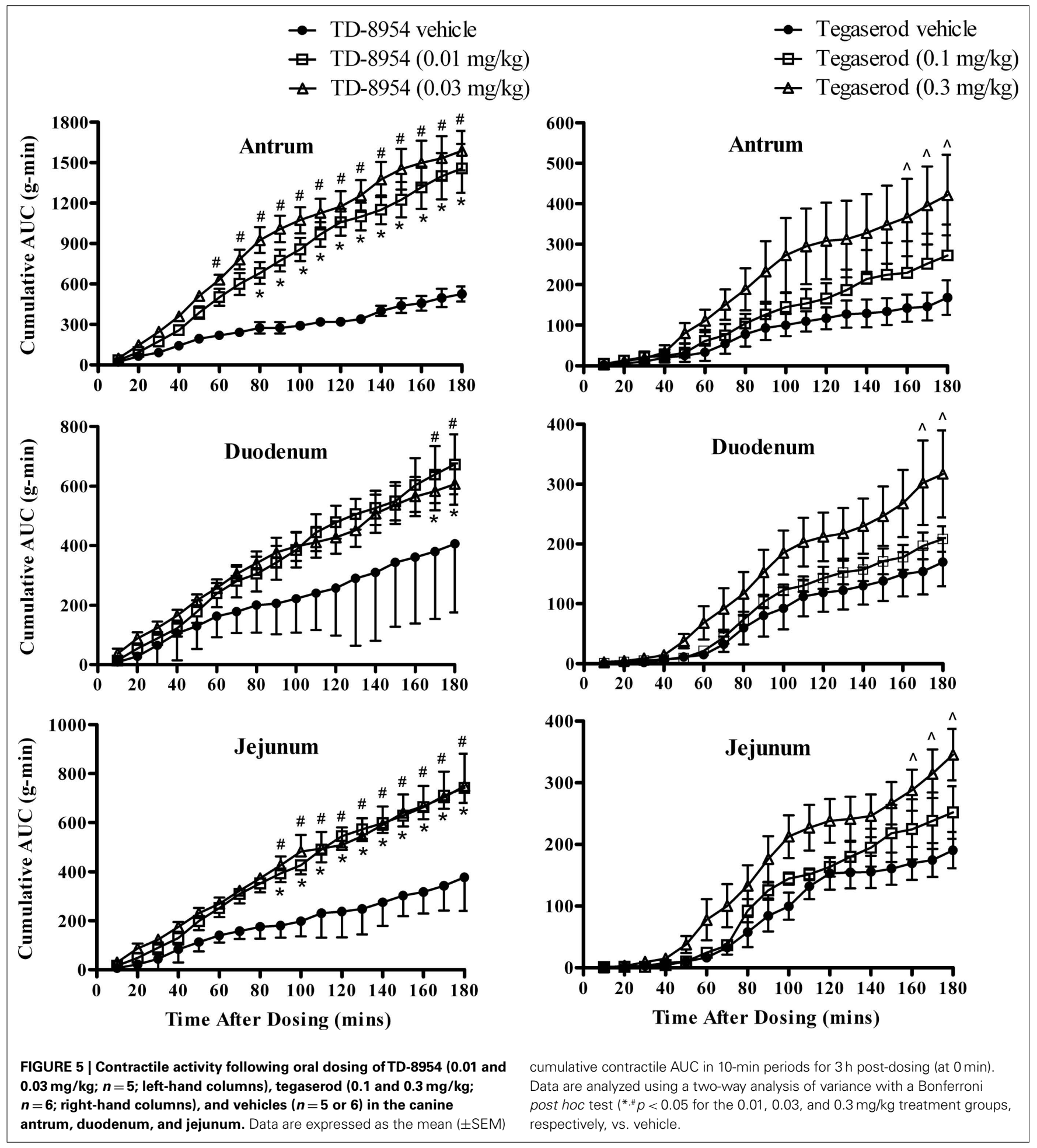

\section{HUMAN SINGLE ASCENDING DOSE STUDY}

In healthy human subjects, GI prokinetic effects of TD-8954 (0.1-20 mg) were observed (Figure 7). The number of bowel movements from 0 to $24 \mathrm{~h}$ after each TD-8954 dose was increased significantly relative to placebo ( $p<0.03$ upon comparison of each TD-8954 treated group and placebo, based on Wilcoxon rank sum test). Compared to placebo, each TD8954 dose was associated with a statistically significant reduction in the time to first bowel movement $(p<0.05$ for all treatment groups comparing difference in survival function between each TD-8954 treated group and placebo obtained by log-rank test). 

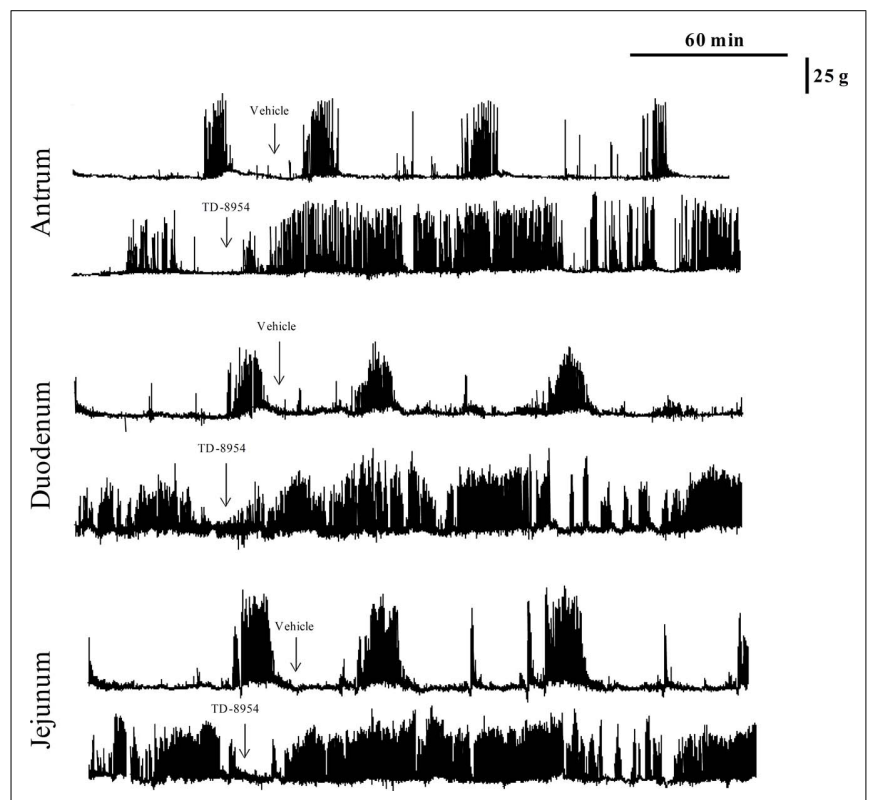

FIGURE 6 | Representative traces demonstrating the effects of oral dosing of TD-8954 $(0.01 \mathrm{mg} / \mathrm{kg})$ and vehicle on the contractility of the antrum, duodenum, and jejunum of conscious, fasted dogs.

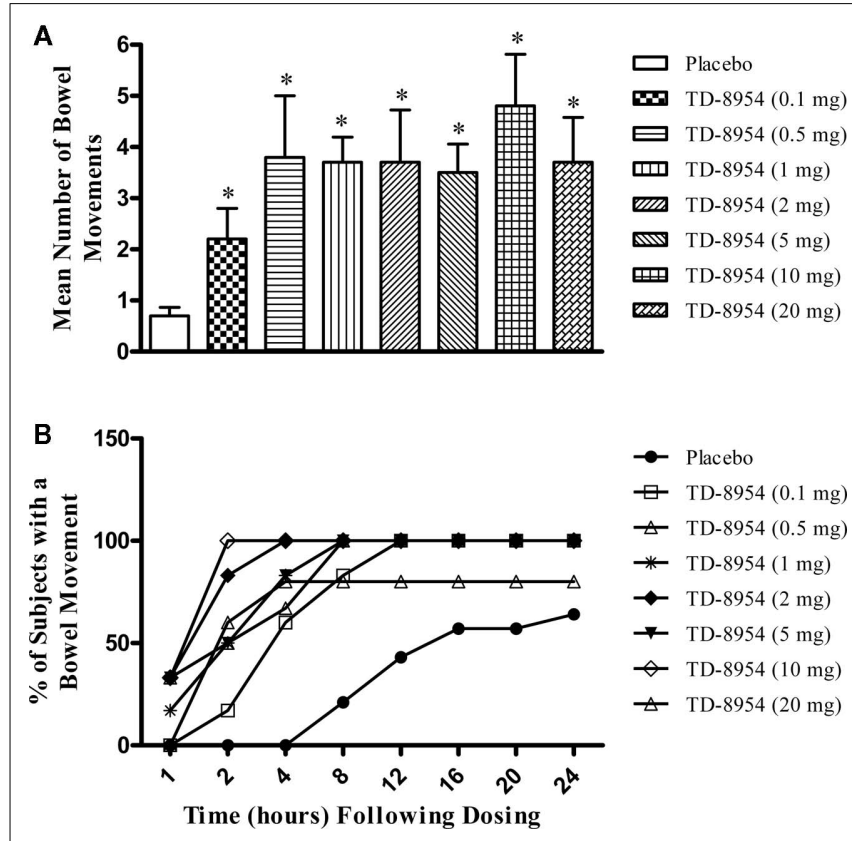

FIGURE 7 | (A) The mean number of bowel movements, and (B) the cumulative percentage of subjects responding with a bowel movement within $24 \mathrm{~h}$ following the oral dosing of TD-8954 $(0.1-20 \mathrm{mg})$ and placebo to healthy human subjects ( $n=5-14$ per group). Each dose of TD-8954 produced a statistically significant effect compared to placebo $\left({ }^{*} p<0.03\right.$, Wilcoxon rank sum test vs. placebo).

\section{DISCUSSION}

Disorders of reduced GI motility, such as IBS-C, chronic idiopathic constipation, gastroparesis, post-operative ileus, and functional dyspepsia have a significant impact on the quality of life of affected individuals. Prior to their removal from the market, cisapride and tegaserod provided some relief to patients afflicted with these disorders (Prather et al., 2000; Evans et al., 2004; Ford et al., 2009). Limitations in their efficacy have been attributed to a lack of selectivity for the $5-\mathrm{HT}_{4}$ receptor subtype (Beattie and Smith, 2008; De Maeyer et al., 2008). Cisapride is a potent $5-\mathrm{HT}_{2 \mathrm{~A}}$ and $5-\mathrm{HT}_{2 \mathrm{~B}}$ receptor antagonist, while tegaserod has affinity for, and/or antagonist potency at, $5-\mathrm{HT}_{1 \mathrm{~B}}, 5-\mathrm{HT}_{2 \mathrm{~A}}$, and $5-\mathrm{HT}_{2 \mathrm{~B}}$ receptors (Buchheit et al., 1995; Beattie et al., 2004; De Maeyer et al., 2008). Interactions of cisapride or tegaserod with non-5-HT receptors have also been proposed to underlie cardiac arrhythmic or ischemic adverse events. It is now well established that cisapride can induce ventricular tachycardia, ventricular fibrillation, and torsades de pointes as a result of potent cardiac hERG potassium channel inhibitory activity, particularly when cytochrome $\mathrm{P}_{450} 3 \mathrm{~A} 4$ substrates are co-administered (Mohammad et al., 1997). The perceived risk of cardiovascular ischemic events with tegaserod, initially identified upon reviewing clinical trial data, has been questioned recently (Anderson et al., 2009; Loughlin et al., 2010). It is clear, however, that a significant unmet medical need remains for new therapeutic agents that will be efficacious and well tolerated in patients with functional GI disorders. One approach has been the development of selective $5-\mathrm{HT}_{4}$ receptor agonists, such as velusetrag (Beattie et al., 2008a; Smith et al., 2008; Goldberg et al., 2010), prucalopride (Briejer et al., 2001a; Camilleri et al., 2008), and TD-8954 (Beattie et al., 2008b), which, it is believed, will provide robust efficacy with acceptable tolerability and safety for patients. TD-8954, the subject of this study, is one of the most potent and selective $5-\mathrm{HT}_{4}$ receptor agonists described to date.

The in vitro data demonstrated that TD-8954 had high affinity and potency at the human $5-\mathrm{HT}_{4}$ receptor $\left(\mathrm{pK}_{\mathrm{i}}\right.$ and $\mathrm{pEC}_{50}$ values of 9.4 and 9.3, respectively). In each assay, TD-8954 was significantly more potent than each of the comparator $5-\mathrm{HT}_{4}$ agonists tested in parallel, an observation consistent with that made previously in experiments with human isolated colonic circular muscle preparations (Beattie et al., 2008b). Activation of the 5$\mathrm{HT}_{4}$ receptor by TD-8954 was confirmed in vitro by antagonist inhibition, where the GR113808 $\mathrm{pK}_{\mathrm{b}}$ value was consistent with the $\left[{ }^{3} \mathrm{H}\right]$-GR113808 binding $\mathrm{pK}_{\mathrm{d}}$ and antagonist $\mathrm{pK}_{\mathrm{b}}$ values reported previously against 5-HT and tegaserod (Smith et al., 2008), providing further evidence of a $5-\mathrm{HT}_{4}$ receptor-mediated elevation of cAMP. TD-8954 had moderate IA at human recombinant 5$\mathrm{HT}_{4}$ receptors and endogenous $5-\mathrm{HT}_{4}$ receptors in the guinea pig colonic LMMP. Optimal target activation to induce a physiological response is dependent upon, amongst other things, the IA of an agonist and the receptor reserve in the target tissue (Grimwood and Hartig, 2009). While TD-8954 had moderate $5-\mathrm{HT}_{4}$ receptor agonist IA in vitro, robust in vivo GI prokinetic or 5$\mathrm{HT}_{4}$ agonist activity, to at least the same degree as standards with higher IA in vitro, was noted in guinea pigs, rats, and dogs. The data suggest that a particularly low level of agonist activity in the in vitro assays (e.g., such as that evident with mosapride) is required before reduced efficacy is observed in vivo, consistent with a large $5-\mathrm{HT}_{4}$ receptor reserve. TD-8954 had $>2,000$-fold selectivity for the human $5-\mathrm{HT}_{4(\mathrm{c})}$ receptor over all other targets tested. Notably, TD-8954, unlike tegaserod or cisapride, had no 
affinity for $5-\mathrm{HT}_{1 \mathrm{~B}}, 5-\mathrm{HT}_{2 \mathrm{~A}}, 5-\mathrm{HT}_{2 \mathrm{~B}}$, or $5-\mathrm{HT}_{3}$ receptors. Also, in contrast to cisapride, TD-8954 had no inhibitory effect at the hERG potassium channel.

The high $5-\mathrm{HT}_{4}$ receptor agonist potency of TD-8954 was also evident in vivo. TD-8954 (0.03-3 mg/kg s.c.) produced a statistically significant increase in colonic transit in conscious guinea pigs. Following TD-8954 administration and injection of carmine red dye into the proximal colon, the time for excretion of the first fecal pellet containing the marker was markedly reduced. The potent prokinetic activity of TD-8954 in this guinea pig model is in keeping with the proposed role of 5-HT and 5- $\mathrm{HT}_{4}$ receptor activation in promoting GI motility (Muller-Lissner, 1987; Jin et al., 1999; Briejer et al., 2001b; Ji et al., 2003). The TD-8954-induced relaxation of the rat esophagus in this study is also consistent with agonist activity at the $5-\mathrm{HT}_{4}$ receptor (Triggle et al., 1988; Reeves et al., 1991). The technique of digital sonomicrometry provides a sensitive method to demonstrate the $5-\mathrm{HT}_{4}$ receptor agonistmediated changes in rat esophageal tone (Armstrong et al., 2006). In conscious, fasted dogs, TD-8954 (10 and $30 \mu \mathrm{g} / \mathrm{kg}$ ) produced a dose-dependent increase in contractility of the antrum, duodenum, and jejunum following oral administration. TD-8954 was clearly more potent than tegaserod throughout the canine GI tract, consistent with its superior $5-\mathrm{HT}_{4}$ agonist potency in vitro and oral pharmacokinetic properties (Theravance, Inc., data on file) in this species. Considering the published data from similar models (Gullikson et al., 1993; Briejer et al., 2001b; Tazawa et al., 2002), the findings of this study are entirely consistent with activation of $5-\mathrm{HT}_{4}$ receptors by TD-8954 in the canine GI tract.

Based on the positive preclinical pharmacodynamic effects of TD-8954, a single ascending dose study was performed in healthy

\section{REFERENCES}

Abell, T. L., Camilleri, M., Dimagno, E. P., Hench, V. S., Zinsmeister, A. R., and Malagelada, J. R. (1991). Longterm efficacy of oral cisapride in symptomatic upper gut dysmotility. Dig. Dis. Sci. 36, 616-620.

Adelson, D. W., and Million, M. (2004). Tracking the moveable feast: sonomicrometry and gastrointestinal motility. News Physiol. Sci. 19, 27-32.

Anderson, J. L., May, H. T., Bair, T. L., Muhlestein, J. B., Horne, B. D., and Carlquist, J. F. (2009). Lack of association of tegaserod with adverse cardiovascular outcomes in a matched case-control study. J. Cardiovasc. Pharmacol. Ther. 14, 170-175.

Armstrong, S. R., McCullough, J. L., and Beattie, D. T. (2006). Measurement of 5-HT4 receptor-mediated esophageal responses by digital sonomicrometry in the anesthetized rat. J. Pharmacol. Toxicol. Methods 53, 198-205.

Baker, D. E. (2005). Rationale for using serotonergic agents to treat irritable bowel syndrome. Am. J. Health Syst. Pharm. 62, 700-711.
Barbey, J. T., Lazzarra, R., and Zipes, D. P. (2002). Spontaneous adverse event reports of serious ventricular arrhythmias, QT prolongation, syncope, and sudden death in patients treated with cisapride. J. Cardiovasc. Pharmacol. Ther. 7, 65-76.

Bass, P., and Wiley, J. (1972). Contractile force transducer for recording muscle activity in unanesthetized animals. J. Appl. Physiol. 32, 567-569.

Beattie, D. T., Armstrong, S. R., Shaw, J. P., Marquess, D., Sandlund, C., Smith, J. A., Taylor, J. A., and Humphrey, P. P. (2008a). The in vivo gastrointestinal activity of TD-5108, a selective $5-\mathrm{HT}(4)$ receptor agonist with high intrinsic activity. Naunyn Schmiedebergs Arch. Pharmacol. 378, 139-147.

Beattie, D. T., Vickery, R. G., Armstrong, S. R., Ropenga, A., Cuthbert, A. W., and Humphrey, P. P. (2008b). TD-8954 is a highly potent and selective 5-HT4 receptor agonist with potential utility in disorders of reduced gastrointestinal motility. Gastroenterology 134(Suppl. 1), A-247.

human subjects. The data demonstrated that TD-8954 was associated with an increase in bowel movement frequency and a reduction in the time to first stool compared to placebo. The high potency noted in the preclinical assays was also noted clinically; a dose as low as $0.1 \mathrm{mg}$ was associated with a prokinetic effect, and $0.5 \mathrm{mg}$ produced a maximal response. The free plasma $C_{\max }$ and $\mathrm{AUC}_{0-24}$ values for TD-8954 following a single dose of $0.5 \mathrm{mg}$ to humans are 3.4 and $36.2 \mathrm{nM} / \mathrm{h}$, respectively. Assuming that the free concentration of TD-8954 in plasma is equivalent to that at its site of action in the GI tract, mean and maximal $5-\mathrm{HT}_{4}$ receptor occupancies in the 24 -h period following a $0.5 \mathrm{mg}$ dose should be approximately 80 and $90 \%$, respectively. This apparent requirement for a high level of receptor occupancy to achieve a maximal agonist response (Grimwood and Hartig, 2009) is consistent with the moderate IA of TD-8954 demonstrated preclinically in the in vitro assays.

\section{CONCLUSION}

TD-8954 is a potent and selective $5-\mathrm{HT}_{4}$ receptor agonist in vitro with robust in vivo GI activity in guinea pigs, rats, dogs, and notably humans. As a result of its demonstrated prokinetic activity in healthy human subjects, TD-8954 may have value in the treatment of patients with disorders of reduced GI motility.

\section{ACKNOWLEDGMENTS}

The authors would like to thank Shanti Amagasu, Courtney Gee, Ngoc Mai, Tina Pham, John Taylor, and Shana Johnson Rabidoux for their assistance with the experiments, and Fei Shen, Uwe Klein, and Ed Moran for their critique of the manuscript.

Beattie, D. T., Smith, J. A., Marquess, D., Vickery, R. G., Armstrong, S. R., Pulido-Rios, T., McCullough, J. L., Sandlund, C., Richardson, C. Mai, N., and Humphrey, P. P. A. (2004). The 5-HT4 receptor agonist, tegaserod, is a potent 5 -HT2B receptor antagonist in vitro and in vivo. Br. J. Pharmacol. 143, 549-560.

Beattie, D. T., and Smith, J. A. M. (2008). Serotonin pharmacology in the gastrointestinal tract: a review. Naunyn Schmiedebergs Arch. Pharmacol. 377, 181-203.

Bender, E., Pindon, A., Van Oers, I., Zhang, Y. B., Gommeren, W., Verhasselt, P., Jurzak, M., Leysen, J., and Luyten, W. (2000). Structure of the human serotonin 5-HT4 receptor gene and cloning of a novel 5HT4 splice variant. J. Neurochem. 74, 478-489.

Blondel, O., Gastineau, M., Dahmoune, Y., Langlois, M., and Fischmeister, R. (1998). Cloning, expression, and pharmacology of four human 5-hydroxytryptamine 4 receptor isoforms produced by alternative splicing in the carboxyl terminus. $J$. Neurochem. 70, 2252-2261.
Briejer, M. R., Akkermans, L. M. A., and Schuurkes, J. A. J. (1995). Gastrointestinal prokinetic benzamides: the pharmacology underlying stimulation of motility. Pharmacol. Rev. 47, 631-651.

Briejer, M. R., Bosmans, J. P., Van Daele, P., Jurzak, M., Heylen, L., Leysen, J. E., Prins, N. H., and Schuurkes, J. A. J. (2001a). The in vitro pharmacological profile of prucalopride, a novel enterokinetic compound. Eur. J. Pharmacol. 423, 71-83.

Briejer, M. R., Prins, N. H., and Schuurkes, A. J. (2001b). Effects of the enterokinetic prucalopride (R093877) on colonic motility in fasted dogs. Neurogastroenterol. Motil. 13, 465-472.

Buchheit, K. H., Gamse, R., Giger, R., Hoyer, D., Klein, F., Klöppner, E., Pfannkuche, H. J., and Mattes, H. (1995). The serotonin 5-HT4 receptor. 1. Design of a new class of agonists and receptor map of the agonist recognition site. J. Med. Chem. 38, 2331-2338.

Camilleri, M. (2001). Review article: tegaserod. Aliment. Pharmacol. Ther. 15, 277-289. 
Camilleri, M., Kerstens, R., Rykx, A., and Vandeplassche, L. (2008). A placebo-controlled trial of prucalopride for severe chronic constipation. N. Engl. J. Med. 358, 2344-2354.

Cheng, Y. and Prusoff, W. H. (1973). Relationship between the inhibition constant (K1) and the concentration of inhibitor which causes 50 per cent inhibition (I50) of an enzymatic reaction. Biochem. Pharmacol. 22, 3099-3108.

De Maeyer, J. H., Lefebvre, R. A., and Schuurkes, J. A. J. (2008). 5-HT4 receptor agonists: similar but not the same. Neurogastroenterol. Motil. 20, 99-112.

Deruyttere, M., Lepoutre, L., Heylen, H., Samain, H., and Pennoit, H. (1987). Cisapride in the management of chronic functional dyspepsia: a multicenter, double-blind, placebo-controlled study. Clin. Ther. $10,44-51$.

Evans, B. W., Clark, W. K., Moore, D. J., and Whorwell, P. J. (2004). Tegaserod for the treatment of irritable bowel syndrome. Cochrane Database Syst. Rev. 141, 44.

Ford, A. C., Brandt, L. J., Young, C., Chey, W. D., Foxx-Orenstein, A. E., and Moayyedi, P. (2009). Efficacy of 5-HT3 antagonists and 5HT4 agonists in irritable bowel syndrome: systematic review and metaanalysis. Am. J. Gastroenterol. 104, 1831-1843.

Foxx-Orenstein, A. E., Kuemmerle, J. F., and Grider, J. R. (1995). The peristaltic reflex induced by mucosal stimuli in human and guinea pig intestine is mediated by distinct mucosal 5-HT receptors. Gastroenterology 108, A600.

Gaster, L. M., Joiner, G. F., King, F. D., Wyman, P. A., Sutton, J. M., Bingham, S., Ellis, E. S., Sanger, G. F., and Wardle, K. A. (1995). N-[(1butyl-4-piperidinyl)methyl]-3,4-di hydro-2H-[1,3] oxazino[3,2-a] indole-10-carboxamide hydrochloride: the first potent and selective 5-HT4 receptor antagonist amide with oral activity. J. Med. Chem. 38, 4760-4763.

Gershon, M. D., and Tack, J. (2007). The serotonin signaling system: from basic understanding to drug development for functional GI disorders. Gastroenterology 132, 397-414.

Goldberg, M., Li, Y.-P., Johanson, J. F., Mangel, A. W., Kitt, M., Beattie, D. T., Kersey, K., and Daniels, O. (2010). Clinical trial: the efficacy and tolerability of velusetrag, a selective 5-HT4 agonist with high intrinsic activity, in chronic idiopathic constipation - a 4-week, randomized, doubleblind, placebo-controlled, doseresponse study. Aliment. Pharmacol. Ther. 32, 1102-1112.

Grider, J. R., Foxx-Orenstein, A. E., and Jin, J. G. (1998). 5Hydroxytryptamine4 receptor agonists initiate the peristaltic reflex in human, rat, and guinea-pig intestine. Gastroenterology 115, 370-380.

Grimwood, S., and Hartig, P. R. (2009). Target site occupancy: emerging generalizations from clinical and preclinical studies. Pharmacol. Therap. 122, 281-301.

Gullikson, G. W., Virina, M. A., Loeffler, R. F., Yang, D. C., Goldstin, B., Wang, S. X., Moummi, C., Flynn, D. L., and Zabrowski, D. L. (1993). SC-49518 enhances gastric emptying of solid and liquid meals and stimulates gastrointestinal motility in dogs by a 5 hydroxytryptamine4 receptor mechanism. J. Pharmacol. Exp. Ther. 264, 240-248.

Hansen, M. B., and Skadhauge, E. (1997). Signal transduction pathways for serotonin as an intestinal secretagogue. Comp. Biochem. Physiol. 118, 283-290.

Hillier, K., Tam, F. S. F., Bunce, K. T., and Grossman, C. (1994). Inhibition of motility induced by the activation of 5-HT1 and 5-HT4 receptor types in isolated human colon smooth muscle. Br. J. Pharmacol. 112, 102P.

Inui, A., Yoshikawa, T., Nagai, R., Yoshida, N., and Ito, T. (2002). Effects of mosapride citrate, a 5-HT4 receptor agonist, on colonic motility in conscious guinea pigs. Jpn. J. Pharmacol. 90, 313-320.

Ito, M., Mueller, U., Kocher, T., Haier, J., Wieczorek, G., and Pfannkuche, H.-J. (2003). Distribution of 5-HT4 receptor splice variants in the human and non-human primate gastrointestinal tract. Neurogastroenterol. Motil. 15, 498.

Ji, S. W., Park, H., Cho, J. S., Lim, J. H., and Lee, S. I. (2003). Investigation into the effects of mosapride on motility of guinea pig stomach, ileum, and colon. Yonsei Med. J. 44, 653-664.

Jin, J. G., Foxx-Orenstein, A. E., and Grider, J. R. (1999). Propulsion in guinea pig colon induced by 5-hydroxytryptamine (HT) via 5-HT4 and 5-HT3 receptors. J. Pharmacol. Exp. Ther. 288, 93-97.
Johanson, J. F. (2004). Review article: tegaserod for chronic constipation. Aliment. Pharmacol. Ther. 20(Suppl. 7), 20-24.

Kadowaki, M., Wade, P. R., and Gershon, M. D. (1996). Participation of 5-HT3, 5-HT4, and nicotinic receptors in the peristaltic reflex of guinea pig distal colon. Am. J. Physiol. 271, G849-G857.

Kaumann, A. J., and Levy, F. O. (2006). 5-hydroxytryptamine receptors in the human cardiovascular system. Pharmacol. Ther. 111 , 674-706.

Kellow, J. E., Cowan, H., Shuter, B., Riley, J. W., Lunzer, M. R., Eckstein, R. P., Höschl, R., and Lam, S.-K. (1995). Efficacy of cisapride therapy in functional dyspepsia. Aliment. Pharmacol. Ther. 9, 153-160.

Kenakin, T. (1997). Pharmacologic Analysis of Drug-Receptor Interaction. Philadelphia: LippincottRaven, 331-373.

Kim, D.-Y., and Camilleri, M. (2000). Serotonin: a mediator of the braingut connection. Am. J. Gastroenterol. 95, 2698-2709.

Kirchgessner, A. L., Tamir, H., and Gershon, M. D. (1992). Identification and stimulation by serotonin of intrinsic sensory neurons of the submucosal plexus of the guinea pig gut: activity-induced expression of Fos immunoreactivity. J. Neurosci. 12, 235-248.

Loughlin, J., Quinn, S., Rivero, E., Wong, J., Huang, J., Kralstein, J., Earnest, D. L., and Seeger, J. D. (2010). Tegaserod and the risk of cardiovascular ischemic events: an observational cohort study. J. Cardiovasc. Pharmacol. Ther. 15, 151-157.

Manabe, N., Wong, B. S., and Camilleri, M. (2010). New-generation 5-HT4 receptor agonists: potential for treatment of gastrointestinal motility disorders. Exp. Opin. Investig. Drugs 19 765-775.

Manini, M. L., Camilleri, M., Goldberg, M., Sweetser, S., Mckinzie, S., Burton, D., Wong, S., Kitt, M. M., Li, Y.-P., and Zinsmeister, A. R. (2009). Effects of Velusetrag (TD5108) on gastrointestinal transit and bowel function in health and pharmacokinetics in health and constipation. Neurogastroenterol. Motil. 22, 42-48.

Medhurst, A. D., Lezoualc'h, F., Fischmeister, R., Middlemiss, D. N., and Sanger, G. J. (2001). Quantitative mRNA analysis of five C-terminal splice variants of the human 5-HT4 receptor in the central nervous system by TaqMan real time RTPCR. Brain Res. Mol. Brain Res. 90, 125-134.

Mohammad, S., Zhou, Z., Gong, Q., and January, C. T. (1997). Blockage of the HERG human cardiac $\mathrm{K}+$ channel by the gastrointestinal prokinetic agent cisapride. Am. J. Physiol. 273, H2534-H2538.

Muller-Lissner, S. A. (1987). Treatment of chronic constipation with cisapride and placebo. Gut 28, 1033-1038.

Pasricha, P. J. (2007). Desperately seeking serotonin... A commentary on the withdrawal of tegaserod and the state of drug development for functional and motility disorders. Gastroenterology 132, 2287-2290.

Patel, S., Berrada, D., and Lembo, A. (2004). Review of tegaserod in the treatment of irritable bowel syndrome. Exp. Opin. Pharmacother. 5, 2369-2379.

Prather, C. M., Camilleri, M., Zinsmeister, A. R., Mckinzie, S., and Thomforde, G. (2000). Tegaserod accelerates orocecal transit in patients with constipation-predominant irritable bowel syndrome. Gastroenterology 118, 463-468.

Reeves, J. J., Bunce, K. T., and Humphrey, P. P. A. (1991). Investigation into the 5-hydroxytryptamine receptor mediating smooth muscle relaxation in the rat esophagus. Br. J. Pharmacol. 102, 1067-1072.

Sanger, G. J. (2008). 5-Hydroxytryptamine and the gastrointestinal tract: where next? Trends Pharmacol. Sci. 29, 465-471.

Sanger, G. J. (2009). Translating 5-HT4 receptor pharmacology. Neurogastroenterol. Motil. 21, 1235-1238.

Smith, J. A., Amagasu, S. M., Hembrador, J., Axt, S., Chang, R., Church, T., Gee, C., Jacobsen, J. R., Jenkins, T., Kaufman, E., Mai, N., and Vickery, R. G. (2006). Evidence for a multivalent interaction of symmetrical, N-linked, lidocaine dimers with voltage-gated $\mathrm{Na}+$ channels. Mol. Pharmacol. 69, 921-931.

Smith, J. A. M., Beattie, D. T., Marquess, D., Shaw, J.-P., Vickery, R. G., and Humphrey, P. P. A. (2008). The in vitro pharmacological profile of TD-5108, a selective 5-HT4 receptor agonist with high intrinsic activity. Naunyn Schmiedebergs Arch. Pharmacol. 378, 125-137. 
Tazawa, S., Masuda, N., Koizumi, T., Kitazawa, M., Nakane, T., and Miyata, H. (2002). KDR-5169, a new gastrointestinal prokinetic agent, enhances gastric contractile and emptying activities in dogs and rats. Eur. J. Pharmacol. 434, 169-176.

Triggle, C. R., Ohia, S. E., and Bieger, D. (1988). 5-Hydroxytryptamineinduced relaxation of rat and mouse oesophageal smooth muscle. Pharmacologist 30, A126.
Vickery, R. G., Mai, N., Kaufmann, E., Beattie, D. T., Pulido-Rios, T., O'Keefe, M., Humphrey, P. P., and Smith, J. A. (2007). A comparison of the pharmacological properties of guinea-pig and human recombinant 5-HT4 receptors. Br. J. Pharmacol. 150, 782-791.

Conflict of Interest Statement: The authors are current or former employees of Theravance, Inc., and may own stock of Theravance, Inc.
Received: 13 April 2011; paper pending published: 30 April 2011; accepted: 16 May 2011; published online: 30 May 2011.

Citation: Beattie DT, Armstrong SR, Vickery RG, Tsuruda PR, Campbell CB, Richardson C, McCullough JL, Daniels $O$, Kersey K, Li Y-P and Kim KHS (2011) The pharmacology of TD-8954, a potent and selective $5-\mathrm{HT}_{4}$ receptor agonist with gastrointestinal prokinetic properties. Front. Pharmacol. 2:25. doi: 10.3389/fphar.2011.00025
This article was submitted to Frontiers in Gastrointestinal Pharmacology, a specialty of Frontiers in Pharmacology. Copyright (c) 2011 Beattie, Armstrong, Vickery, Tsuruda, Campbell, Richardson, McCullough, Daniels, Kersey, Li and Kim. This is an open-access article subject to a non-exclusive license between the authors and Frontiers Media SA, which permits use, distribution and reproduction in other forums, provided the original authors and source are credited and other Frontiers conditions are complied with. 